\title{
LARVICIDAL ACTIVITY OF TWO RUTACEAE SPECIES AGAINST THE VECTORS OF DENGUE AND FILARIAL FEVER
}

\author{
Grace Marin ${ }^{1}$, Subramanian Arivoli ${ }^{2}$, Samuel Tennyson ${ }^{3 *}$
}

${ }^{1}$ Department of Zoology, Scott Christian College, Nagercoil 629 003, Tamil Nadu, India

${ }^{2}$ Department of Zoology, Thiruvalluvar University, Vellore 632 115, Tamil Nadu, India

${ }^{3}$ Department of Zoology, Madras Christian College, Chennai 600 059, Tamil Nadu, India

Received - January 22, 2020; Revision - March 12, 2020; Accepted - April 03, 2020

Available Online - April 25, 2020

DOI: http://dx.doi.org/10.18006/2020.8(2).166.175

KEYWORDS
Citrus sinensis
Murraya koenigii
Aedes aegypti
Culex quinquefasciatus
Larvicidal

\begin{abstract}
Mosquito control strategies have been primarily dependent on the use of synthetic chemical insecticides but its long-term stability and its tendency to bioaccumulate have fostered many environmental and human health concerns resulting in increase of resistance to chemical insecticides and rebounding vectorial capacity by mosquitoes. Botanical insecticides serve as suitable alternatives to synthetic ones as they are relatively effective, and are safe to environment, human, and animal life. In the present study, Citrus sinensis and Murraya koenigii leaf powders were tested separately on the third instar larvae of Aedes aegypti and Culex quinquefasciatus at concentrations of 0.2, 0.4, 0.6, 0.8 and 1.0\%. Larval mortality was assessed after 24, 48, 72 and 96 hours and their respective $\mathrm{LC}_{50}$ values for $C$. sinensis were $0.69,0.54,0.48$ and $0.36 \%$ for $A$. aegypti; and $0.61,0.53,0.44$ and $0.34 \%$ for $C$. quinquefasciatus. For, M. koenigii, it was $1.05,0.73,0.38$ and $0.24 \%$; and $0.54,0.50,0.32$ and $0.22 \%$ for $C$. sinensis respectively. Amongst tested two botanicals, $C$. sinensis was found to be more active against $C$. quinquefasciatus in dose and time dependent manner and the impact of phytochemicals on expression of $C$. quinquefasciatus protein analysed by SDS-PAGE revealed that the phytochemicals from $C$. sinensis suppressed the expression of certain proteins present in C. quinquefasciatus. Hence, this study confirms and recommends that use of $C$. sinensis and M. koenigii safe and eco-friendly and could use as an alternative to synthetic pesticides in vector control.
\end{abstract}

* Corresponding author

E-mail: samtennyson@gmail.com (Samuel Tennyson)

Peer review under responsibility of Journal of Experimental Biology and Agricultural Sciences.

Production and Hosting by Horizon Publisher India [HPI] (http://www.horizonpublisherindia.in/).

All rights reserved.
All the articles published by Journal of Experimental Biology and Agricultural Sciences are licensed under a Creative Commons Attribution-NonCommercial 4.0 International License Based on a work at www.jebas.org.

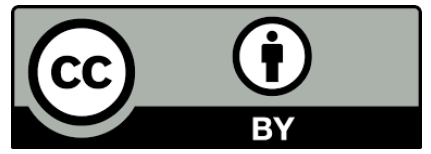




\section{Introduction}

Insect transmitted disease remains a major source of illness and death worldwide of which vector-borne diseases are responsible for $17 \%$ of the global burden of parasitic and infectious diseases (WHO, 2014). Mosquitoes are tremendous public health pests because of their predominance as marketers of potentially deadly pathogens of human beings and the annoyance of skin reactions caused by their bites. Most of the mosquito control programmes target the larval stage in their breeding sites with larvicides (Elimam et al., 2009). Most of the mosquito control techniques have depended on the use of artificial chemical insecticides (Hemingway et al., 2006). However, the unfriendly effect of most of these synthetic chemical insecticides leads the insect pest managers of the world to comb for alternative ways of countering this disease causing insect (Ileke \& Ogungbite, 2015). Also, the long-term stability of many of these chemical insecticides and their tendency to bioaccumulate in non-target organisms have fostered many environmental and human health concerns such as the threats faced due to resulting in increase of resistance to chemical insecticides and rebounding vectorial capacity by mosquitoes (Senthilkumar et al., 2008). Botanical insecticides may serve as suitable alternatives to synthetic ones in future, as they are relatively effective, and safe to environment, human, and animal life (Pitasawat et al., 2007; Borah et al., 2010). Research from all over the world have documented the effect of various phytochemical compounds against a wide range of mosquito species (Samuel et al., 2016; Pathak et al., 2018; Huang et al., 2019; Kaushik et al., 2019; Samuel et al., 2019; Nathan, 2020).

The Rutaceae family comprises of 150 genera and 1,600 species of trees, shrubs, and climbers distributed throughout the temperate and tropical regions of the world (Pollio et al., 2008). The important genera of this family are Citrus, Fortunella, Murraya, Ptelea, Ruta and Zanthoxylum (Siddique et al., 2012). Most of the Rutaceae plants are aromatic whose leaves, fruits or cotyledon in seeds contain a complex mixture of volatile aroma compounds (Aziz et al., 2010); which are used in perfumery, gastronomy and traditional medicine. In addition, various researchers have reported the presence of various secondary metabolites viz., alkaloids, coumarins, flavonoids, limonoids, and volatile oils from family Rutaceae, these metabolites are associated to different biological activities such as antimicrobial (Ali et al., 2008), antidiarrhoeal (Mandal et al., 2010), anticholinesterasic (Cardoso-Lopes et al., 2010), antileishmanial (Andres et al., 2011), antiprotozoal (Severino et al., 2009), antioxidant (Wansi et al., 2006), and mosquito larvicidal (Rajkumar \& Jebanesan, 2008; Arivoli \& Samuel, 2011; Arivoli et al., 2015) properties. Consequently, this study was conducted to determine the larvicidal efficacy of $C$. sinensis and $M$. koenigii leaves as an alternative to synthetic insecticides for the management of $A$. aegypti and C. quinquefasciatus.

\section{Materials and Methods}

\subsection{Plant collection and preparation of phytopowders}

Mature and healthy leaves of $C$. sinensis and M. koenigii were collected from Nagercoil, Kanyakumari district, Tamil Nadu, India and identified taxonomically and confirmed at the Department of Botany and Research Centre, Nagercoil, Kanyakumari district, Tamil Nadu, India. In the laboratory, dechlorinated water was used to wash the leaves and thereafter these leaves were shade dried. Leaves of each plant $(1 \mathrm{Kg})$ was then powdered by an electric blender and was stored in air tight sterilized amber coloured bottles for bioassay.

\subsection{Phytochemical screening}

The active phytochemical compounds in C. sinensis and $M$. Koenigii leaf powders were qualitatively determined using methods described by Harborne (1998) for alkaloids, glycosides, steroids, phenolics and carbohydrates, Van Burden \& Robinson (1981) for tannins and proteins, Obadoni \& Ochuko (2001) for saponins, Boham \& Kocipai (1974) for flavonoids, and Okwu \& Okwu (2004) for vitamins.

\subsection{Fourier Transform Infrared Spectroscopy (FTIR)}

FTIR is the most powerful tool for identifying functional groups present in plant extracts. Dried methanol extract powder (10mg) of each plant was encapsulated in $100 \mathrm{mg}$ of $\mathrm{KBr}$ pellet, in order to prepare translucent sample discs. The powdered samples were loaded in FTIR spectroscope (Shimadzu, Japan), with a scan range from 400 to $4000 \mathrm{~cm}^{1}$ (Visveshwari et al., 2017).

\subsection{Sodium Dodecyl sulphate - PolyAcrylamide Gel Electrophoresis (SDS - PAGE) analysis}

SDS-PAGE is the most widely used analytical method to resolve separate components of a protein mixture. It is almost obligatory to assess the purity of a protein through an electrophoretic method. SDS-PAGE simultaneously exploits differences in molecular size to resolve proteins differing by as little as $1 \%$ in their electrophoretic mobility through the gel matrix. The technique is also a powerful tool for estimating the molecular weights of proteins. The molecular weight of the protein was estimated using a high molecular weight protein calibration kit (Merck, Bangalore, India) as markers. The molecular mass markers (expressed in Da) used were myosin $(205,000), \quad \beta$-galactosidase $(11,600)$, phosphorylase b $(97,400)$, bovine serum albumin $(66,000)$, ovalbumin $(43,000)$, carbonic anhydrase $(29,000)$, soyabean trypsin inhibitor $(20,100)$ and lysozyme $(14,300)$.

Total protein was extracted by using acetone- TCA (Trichloro Acetic Acid) precipitation technique of Damerval et al. (1986) and the 
estimation of protein was executed according to the methodology of Lowry et al. (1951). Every sample $(0.5 \mathrm{~g})$ with a buffer $(2 \mathrm{~mL})$ containing Tris (hydroxymethyl) aminomethane (Tris)-Glycine $(\mathrm{pH}$ $8.3)(50 \mathrm{mM})$, sucrose $(0.5 \mathrm{M})$, EDTA $(50 \mathrm{mM})$, potassium chloride $(0.1 \mathrm{M})$, PMSF $(2 \mathrm{mM})$ and $0.1 \%(\mathrm{v} / \mathrm{v})$ 2-mercaptoethanol was homogenized at $4^{\circ} \mathrm{C}$ in a chilled pestle and mortar. The homogenate was centrifuged at $14000 \mathrm{rpm}$ for 10 minutes in a refrigerated centrifuge. The concentration of protein in supernatant samples were assessed according to the technique of Bradford (1976) and gels prepared as per the protocol adopted by Laemmli (1970). A separating gel $(12.0 \%)$ was used for resolving the polypeptides which comprised of Tris- $\mathrm{HCl}(375 \mathrm{mM}), \mathrm{pH} 8.8,0.1 \%$ (w/v) SDS, $0.05 \%(\mathrm{w} / \mathrm{v})$ ammonium persulfate and $0.4 \mu \mathrm{LmL}^{-1}$ TEMED. For a stacking gel (4\%) used to concentrate (stack) the polypeptides, it comprised of Tris- $\mathrm{HCl}(125 \mathrm{mM}), \mathrm{pH} 6.8,0.1 \%$ (w/v) SDS, $0.05 \%$ $(\mathrm{w} / \mathrm{v})$ ammonium persulfate and $0.5 \mu \mathrm{LmL}^{-1}$ TEMED. The electrophoresis running buffer was made of Tris $(25 \mathrm{mM})$, glycine $(192 \mathrm{mM})$, SDS $(0.1 \%)$ with $\mathrm{pH} 8.3$, and was accomplished for 4 hours at $35 \mathrm{~mA}$. The gels were stained for two hours with Coomassie Brilliant Blue R-250 (Sigma) $(0.25 \%)$ in $50 \%$ (v/v) methanol and $(\mathrm{v} / \mathrm{v})$ acetic acid $(10 \%)$ and then destained with methanol and acetic acid until a clear background was obtained.

\subsection{Vector mosquitoes}

Insecticide free $A$. aegypti eggs and $C$. quinquefasciatus egg rafts were obtained from Entomology Research Institute, Loyola College, Chennai, Tamil Nadu, India. Cyclic generations of the above mentioned vector mosquitoes were maintained separately in two feet mosquito cages with a mean room temperature of $27 \pm 2^{\circ} \mathrm{C}$ and a relative humidity of $70-80 \%$ inside an insectary and the adults were fed on $10 \%$ glucose solution in water. Ovitraps were placed inside the mosquito cages for the female mosquitoes to oviposit eggs and the laid eggs were then transferred to the larval rearing chamber and were maintained in enamel larval trays. The larvae fed with larval food (dog biscuits and yeast in the ratio $3: 1$ ) on becoming pupae were transferred to plastic bowls kept inside another mosquito cage for emergence of adults.

\subsection{Larvicidal bioassay}

According to the guidelines of World Health Organization (WHO, 2005) with minor modifications, bioassays were performed on twenty five $F_{1}$ generation of laboratory colonized third instar larvae of the above mentioned vector species at test concentrations of (w/v) $0.2,0.4,0.6,0.8$ and $1.0 \%$ by introducing them into glass beakers $(250 \mathrm{~mL})$ containing $200 \mathrm{~mL}$ of distilled water and test concentration. One per cent stock solution for each plant powder was prepared by dissolving $1 \mathrm{~g}$ of each leaf powder in $100 \mathrm{~mL}$ distilled water, from which the above mentioned concentrations were arrived. Third instar larvae formed the choice as the research sample, compared to first and second instar since they possessed a larger body size and are more adaptive to the environment; while fourth instar transforms to a pupa in approximately 48 hours (Marin et al., 2020). Control (distilled water) was run simultaneously and maintained separately. Bioassays were performed with five replicates for each concentration per trial with a total of three trials. Larval mortality was observed 24, 48, 72 and 96 hours after treatment and moribund larvae were recorded dead when they displayed no signs of movement when probed by a needle at their respiratory siphon.

\subsection{Statistical analysis}

Data was subjected to statistical analysis with significance set at 95\% confidence in IBM SPSS Statistics v22 (SPSS, 2010). Per cent larval mortality was calculated and corrections for control mortality (5-20\%) if required was carried according to Abbott's formula (Abbott, 1925) and then larval mortality were subjected to probit analysis. Analysis of variance (ANOVA) of larval mortality was performed to measure differences between treated bioassays and controls and at which doses in particular and the differences were considered significant at $P \leq 0.001$ level.

$$
\frac{1-n \text { in T after treatment }}{n \text { in } \mathrm{C} \text { after treatment }} \times 100
$$

Where, $n$ is the number of larvae, T: treated and C: control. 3 Results

The qualitative phytochemical analysis of $C$. sinensis and $M$. koenigii leaves are presented in Table 1. The FTIR spectrum of $C$. sinensis showed the presence of alcohol, alkenes, aromatic amines, phenyl, ether, methylene, $1^{\circ}$ and $2^{\circ}$ amines and aliphatic chloro compound. The major band was observed at $3308 \mathrm{~cm}^{-1}$ due to $\mathrm{O}-\mathrm{H}$ stretching vibrations of alcohol group (Figure 1). M. koenigii

Table 1 Phytochemical composition of Citrus sinensis and Murraya koenigii leaves

\begin{tabular}{|c|c|c|c|c|c|c|c|c|c|}
\hline \multirow{2}{*}{ Plant species } & \multicolumn{9}{|c|}{ Phytocompounds } \\
\hline & Alkaloids & Carbohydrates & Flavonoids & Glycosides & Phenols & Proteins & Saponins & Steroids & Tannins \\
\hline Citrus sinensis & +++++ & +++ & ++ & ++++ & ++++ & ++++ & +++++ & ++++ & +++++ \\
\hline Murraya koenigii & +++++ & ++++ & +++++ & +++ & +++ & ++++ & +++++ & - & +++ \\
\hline
\end{tabular}

+++++ Above $80 \%$; ++++ 50-75\%; +++ Below 50\%; ++ Below 25\%; and - Nil 

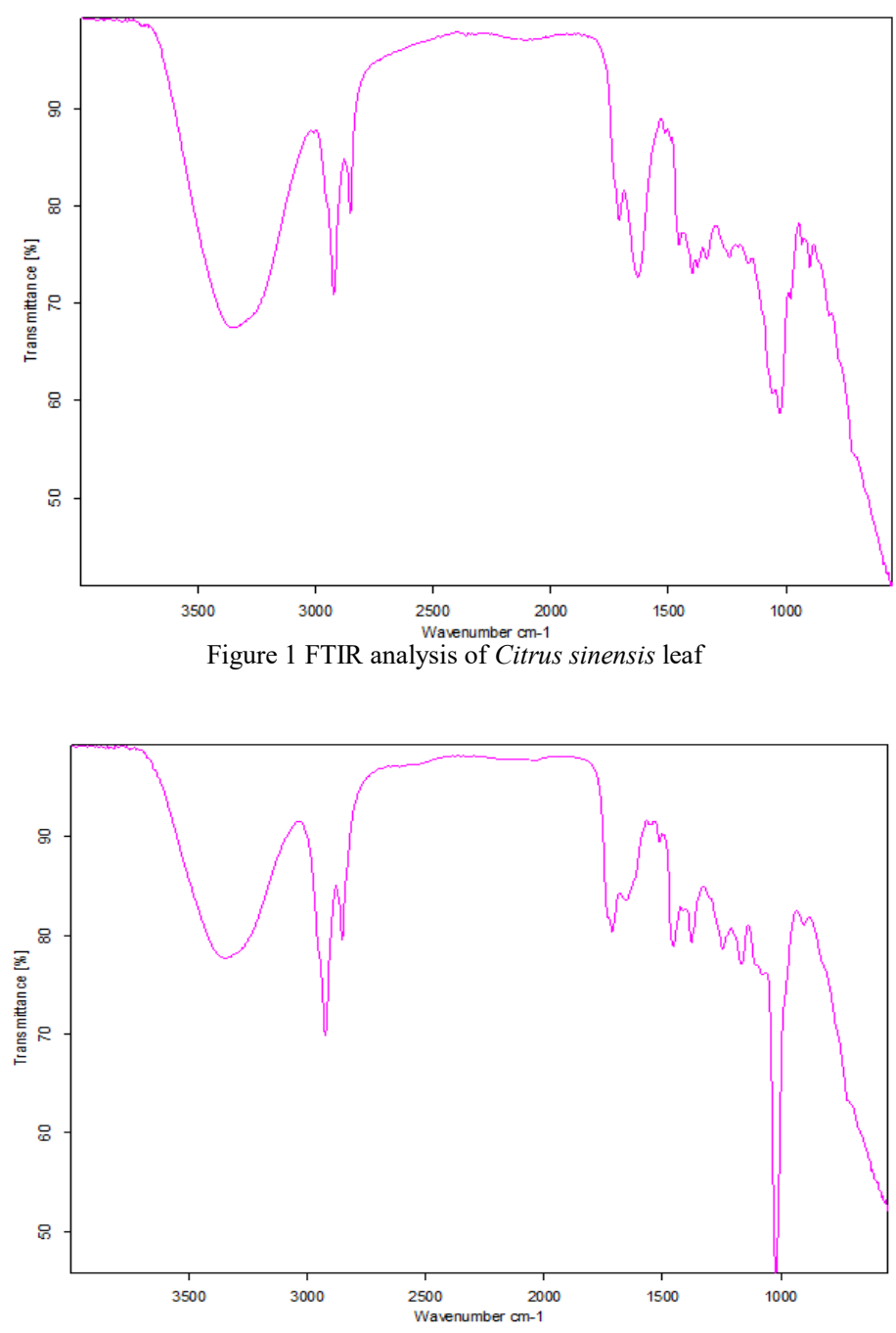

Figure 2 FTIR analysis of Murrayakoenigii leaf indicated the presence of alcohol, alkenes, aromatic amines, phenyl, ether, methylene, cyclic ether and vinyl groups. The major band was observed at $3398.2 \mathrm{~cm}^{-1}$ due to $\mathrm{O}-\mathrm{H}$ stretching vibrations of alcohol group (Figure 2).

No larval mortality was observed in control. The percentage mortality of $A$. aegypti and $C$. quinquefasciatus larva treated with the various concentrations of $C$. sinensis after 24, 48, 72 and 96 hours are presented in Figure 3 and 4 and its $\mathrm{LC}_{50}$ values were reported $0.69,0.54,0.48$ and $0.36 \%$; and 0.61 , $0.53,0.44$ and $0.34 \%$ respectively. One Way ANOVA, comparing treated and control group, with a significance level established at $P<0.001$ showed that $C$. sinensis concentrations significantly influenced the mortality of larvae; F value 82.52 for $A$. aegypti and 59.46 for $C$. quinquefasciatus. In the case of $M$. koenigii, the percentage mortality of $A$. aegypti and $C$. quinquefasciatus after 24, 48, 72 and 96 hours are presented in Figure 5 and 6 and its $\mathrm{LC}_{50}$ values are 1.05, $0.73,0.38$ and $0.24 \%$; and $0.54,0.50,0.32$ and $0.22 \%$ respectively. One Way ANOVA, comparing treated and control group, with a significance level established at $P<0.001$ showed that $M$. koenigii concentrations significantly influenced the mortality of larvae, $\mathrm{F}$ value 30.27 for A. aegypti and 21.81 for C. quinquefasciatus. $C$. sinensis was found to be more effective against third instar larvae of $C$. quinquefasciatus. Hence, these mosquito larvae treated with $C$. sinensis leaf powder were further investigated to reveal the impact of phytochemicals on their proteins. SDS-PAGE analysis revealed that the phytochemicals from $C$. sinensis suppressed the expression of certain proteins present in C. quinquefasciatus (Figure 7).

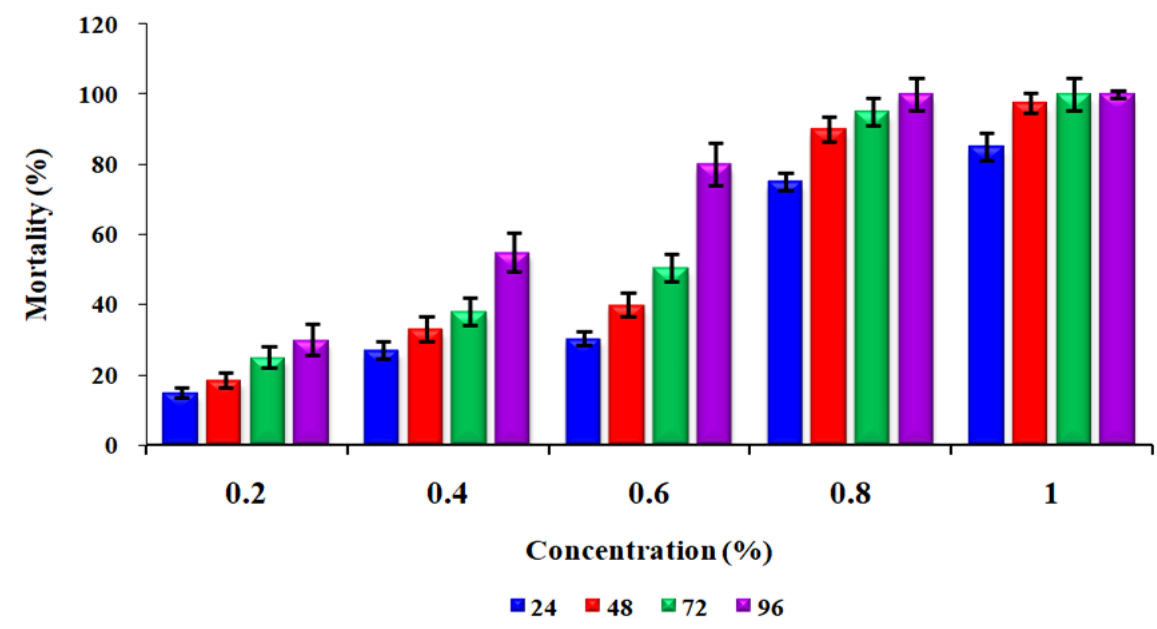

Figure 3 Per cent larval mortality of Aedes aegypti by Citrus sinensis

Journal of Experimental Biology and Agricultural Sciences http://www.jebas.org 


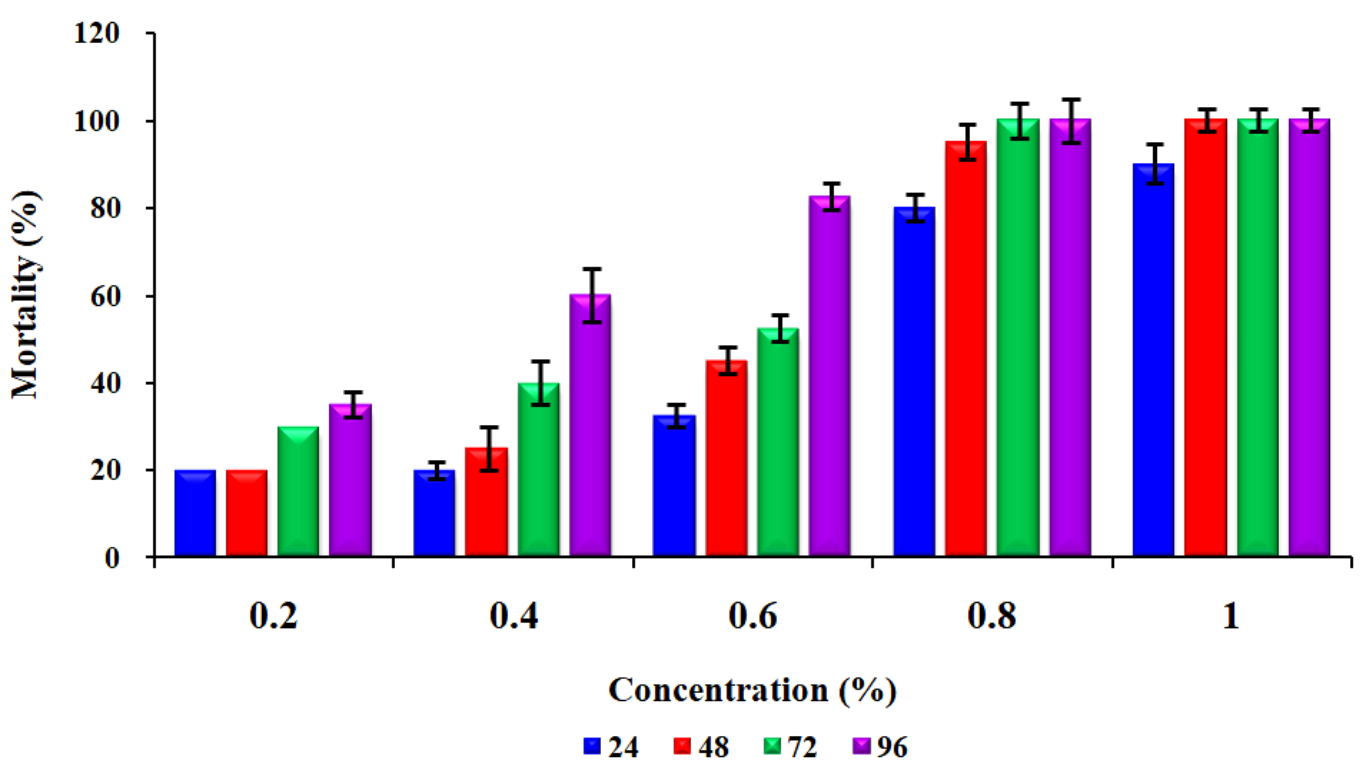

Figure 4 Per cent larval mortality of Culex quinquefasciatus by Citrus sinensis

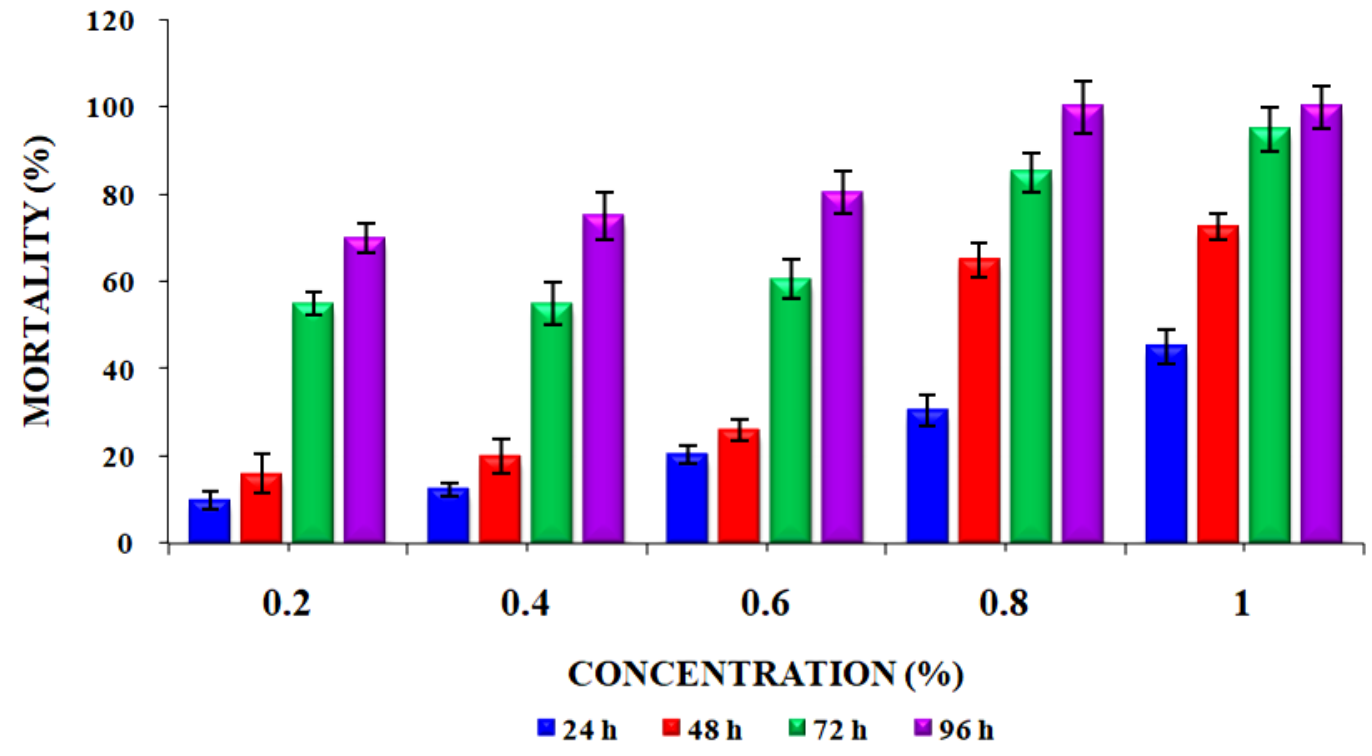

Figure 5 Per cent larval mortality of Aedes aegypti by Murraya koenigii 


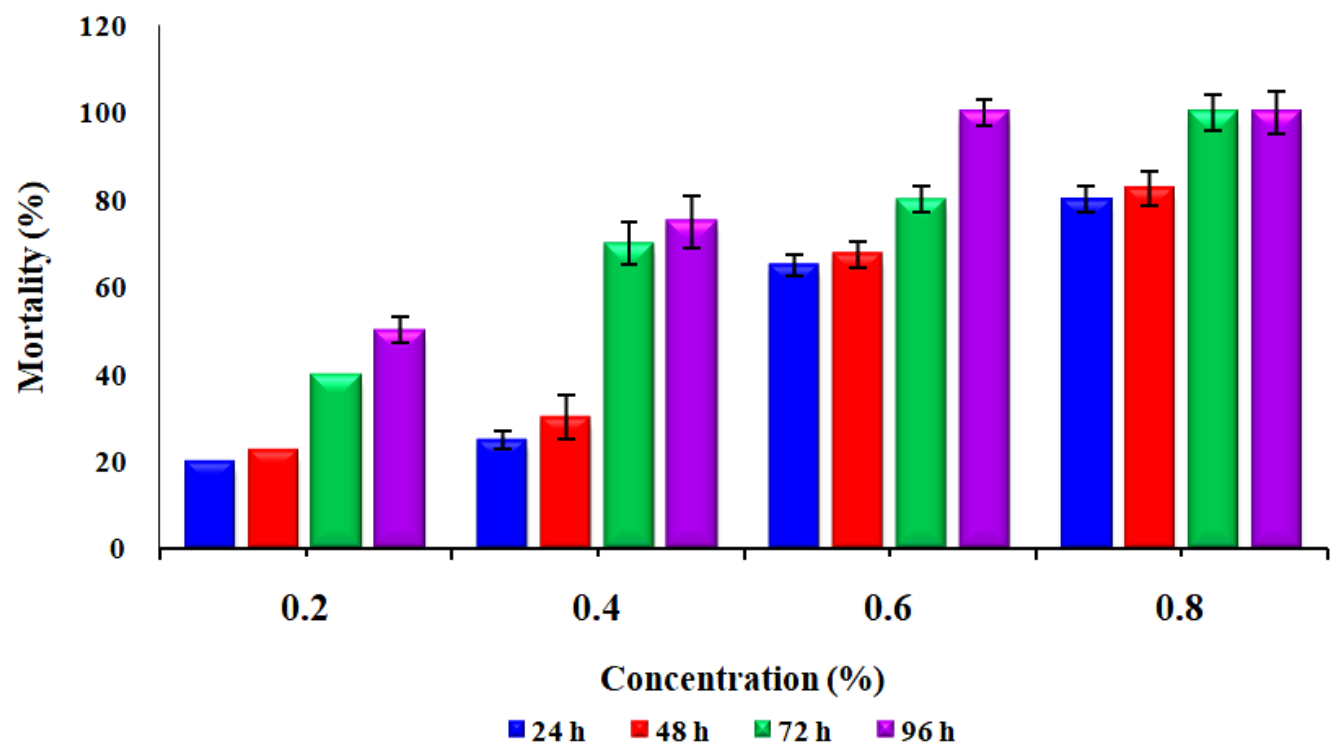

Figure 6 Per cent larval mortality of Culex quinquefasciatus by Murraya koenigii

1

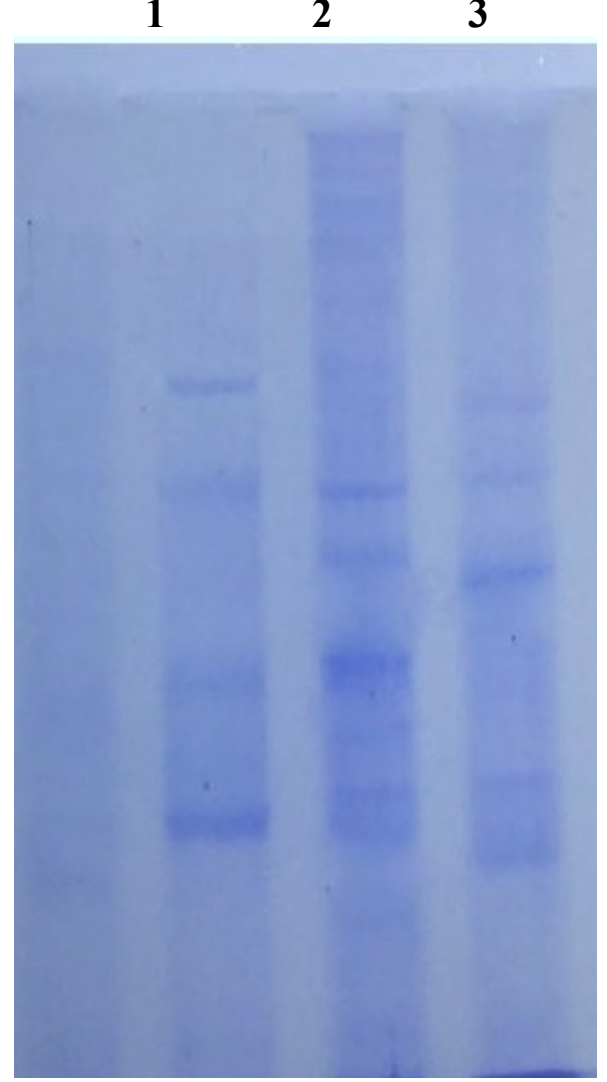

Figure 7 SDS PAGE analysis of proteins from Culex quinquefasciatus Lane 1:Molecular weight marker; Lane 2:Control larva; and Lane 3:Treated larva

\section{Discussion}

Mosquito control is vital and is still in a state of evolution, dependent upon synthetic organic insecticides, many of which have been removed from the arsenal of weapons (Das et al., 2007) and botanicals replaced as the new weapons. Vector control is preferably performed at the larval stage, due to its larger vulnerability (Zoubiri \& Baaliouamer, 2014). The activities of botanicals are often attributed to the complex mixture of their phytochemical active compounds. Plant families, viz., Asteraceae, Boraginaceae, Fabaceae, Piperaceae and Rutaceae (Garcez et al., 2013) are highlighted as producers of compounds with larvicidal activity. Results of current study revealed that both plants are rich sources of bioactive compounds and have great potential of eradicating mosquito larvae (Ghosh et al., 2012; Samuel \& William, 2014; Pathak et al., 2018; Kaushik et al., 2019; Nathan, 2020). Among these two, $C$. sinensis was found more efficient against $C$. quinquefasciatus in dose and time dependent manner. $C$. sinensis also has an intense larvicidal activity against Anopheles. labranchiae (El-Akhal et al., 2015) and A. aegypti (Galvao et al., 2015) besides acting as a potent fumigant against mosquitoes (Ezeonu et al., 2001). Similarly, Sattar et al. (2016) also reported the larvicidal property of $C$. sinensis leaf powder against $C$. quinquefasciatus. Also, the results of the present study are in accordance with Bilal et al. (2012) who have reported that the leaf extract of $C$. sinensis exhibited $97 \%$ mortality against $A$. albopictus larva. Similarly, Murugan et al. (2012) studied the effect of ethanol peel extract of $C$. sinensis against Anopheles stephensi, A. aegypti and $C$. quinquefasciatus larvae and reported their $\mathrm{LC}_{50}$ values

Journal of Experimental Biology and Agricultural Sciences http://www.jebas.org 
291.69, 342.45, and 385.32ppm respectively. Warikoo et al. (2012) also testified the activity of hexane extract of $C$. sinensis leaf extract against $A$. aegypti larvae and reported $446.84 \mathrm{ppm} \mathrm{LC}_{50}$ value. George (2019) stated that the aqueous peel extract of $C$. sinensis caused $100 \%$ larval mortality in Anopheles species at $2.0 \mathrm{~g} / \mathrm{mL}$ for 24 hours exposure. The results of the present study also validates with the report of Arivoli \& Samuel (2011) who investigated the larvicidal effect of different solvent extracts of $M$. koenigii leaves against A. aegypti, An. stephensi and $C$. quinquefasciatus larvae and confirmed the presence of various active substances. Arivoli et al. (2015) reported that the hexane fraction of M. koenigii leaves produced 100, 99.2 and 97.6\% larval mortality rate at $100 \mathrm{ppm}$ after 24 hours against $A$. aegypti, $C$. quinquefasciatus and An. stephensi respectively.

Mortality of larvae is related to the phytochemical constituents present in the leaves of $C$. sinensis and M. koenigii. Active ingredients in botanical derivatives owning mosquitocidal properties due to the presence of alkaloids, flavonoids, steroids, tannins, terpenes and terpenoids (Scherer et al., 2010; Farooq et al., 2014) directly spasm the nervous system, disturb the mid-gut epithelium and secondarily distress the gastric caeca and malpighian tubules in mosquito larvae (Rey et al., 1999). Further, they act as mitochondrial poison (Mann \& Kaufman, 2012), and work by means of networking and intermingling with the larvae cuticle membrane, and ultimately disarranging the membrane which would be the utmost probable reason for larval death (Hostettmann \& Marston, 1995). The larvicidal activity of $C$. sinensis might be due to the high quantity of alkaloids, saponins and tannins. Kumar et al. (2012) reported the presence of alkaloids, flavonoids and terpenoids in the petroleum ether leaf extracts of $C$. sinensis which caused mortality in A. aegypti larvae. Musau et al. (2016) suggested that alkaloids act as anticholinesterases that bind to acetylcholine enzymes and disrupts the membrane integrity, impair microtubules functioning and could cause impairment in digestive system by inhibiting hydrolytic enzyme. Further, these alkaloids slow down larval movement by interfering nerve impulse transmission (Mansour et al., 1998; Armadhani, 2014). Phytochemical saponins are toxic as they disrupt the oxygen supply to larvae and disrupts the larvae before it could pupate (Bagavan et al., 2008; Chapagain et al., 2008). Tannins work as a stomach poison and can interfere with the larvae digestion process by binding with proteins in the digestive system (Boudko et al., 2011). On the other hand, M. koenigii extract is also a rich source of alkaloids, saponins and flavonoids and larvicidal properties shown in current study might be due to the presence of these chemicals. Results of current study are in agreement with the findings of Sukari et al. (2013) who reported the larvicidal property of M. koenigii phytocompounds against $A$. aegypti. According to Palanikumar et al. (2017) flavonoids available in $M$. koenigii inhibits the larval respiration and disrupts the transport of electrons as they enter through the respiratory siphon and are forwarded to trachea throughout the body and attacks the central nerve ganglion which gets disturbed, which leads to paralysis of nerve cells and eventually death of mosquito larvae (Adnyani \& Sudarmadja, 2016). Further, this plant is rich in coumarins, acridine alkaloids and carbazole alkaloids (Ito, 2000). Apart from the specific role of certain compound, synergistic effect of closely related compounds in plants could also contribute to death of mosquito larvae (Isman, 1997).

SDS-PAGE analysis of proteins from third instar of $C$. quinquefasciatus revealed the absence of some of the proteins when treated with $C$. sinensis. In the control sample, 13 protein bands were clearly visible after CBB staining; however in the treated mosquito sample only nine proteins were visualized. This is mainly due to suppression or inhibition of protein synthesis by phytochemicals. These phytochemicals enter into the body of mosquito larvae through digestive tract and by diffusion. The reduction in protein level in the treated mosquito larvae has been reported previously in Culex larvae by the action of Artemisia апnиa extract which caused a ruptured and degenerated body wall of larval tissues (Sharma et al., 2006). Senthilkumar et al. (2009) reported that protein levels in An. stephensi larvae treated with Annona squamosa, Artemisia annua, Centella asiatica, Cymbopogan citratus, Eucalyptus globulus, Justicia gendarussa and Myristica fragrans extracts were reduced and resumed that it was the result of interference of the phytochemicals with normal protein synthesis mechanism. In general, protein is the essential element of the animal body as well as insect structure. Its higher amount in their body indicates larger body mass, which establishes higher reproductive success in insects, improved competitive ability (Warren et al., 2006), and disease vulnerability and stress resistance (Lee et al., 2008; de Souza Wuillda, 2019).

\section{Conclusion}

In conclusion, the present study established the larvicidal activity of the two Rutaceae species against $A$. aegypti and $C$. quinquefasciatus. Botanicals are one of the best alternatives to their synthetic counterpart and this study confirms and recommends that $C$. sinensis and $M$. koenigii are safe and ecofriendly alternative of synthetic pesticides in vector control. However, the mechanism of action and the structure activity relationship for larvicidal activity remain unclear. Therefore, understanding the mechanism of action of secondary metabolites with larvicidal action can help in reducing the resistance of insecticides and aid the production of analogs with more pronounced activity with specific or multiple sites of action.

\section{Conflict Of Interest}

Authors would hereby like to declare that there is no conflict of interests that could possibly arise. 


\section{References}

Abbott WS (1925) A method of computing the effectiveness of an insecticide. Journal of Economic Entomology 18: 265-267.

Adnyani IGAP, Sudarmadja IM (2016) Pengaruh Konsentrasi Ekstrak Etanol Daun Pepaya (Carica papaya L) terhadap Kematian Larva Nyamuk Aedes aegypti. E-Jurnal Medika 5: 1-5.

Ali MS, Fatima S, Pervez MK (2008) Haplotin: A new furanoquinoline from Haplophyllum acutifolium (Rutaceae). Journal of the Chemical Society of Pakistan 30: 775-779.

Andres CCA, Barrera CED, Falla GDS, Murcia DG, Suarez CLE (2011) Seco-limonoids and quinoline alkaloids from Raputia heptaphylla and their antileishmanial activity. Chemical and Pharmaceutical Bulletin 59: 855-859.

Arivoli S, Raveen R, Samuel T (2015) Larvicidal activity of Murraya koenigii (L.) Spreng (Rutaceae) hexane leaf extract isolated fractions against Aedes aegypti Linnaeus, Anopheles stephensi Liston and Culex quinquefasciatus Say (Diptera: Culicidae). Journal of Mosquito Research 5: 1-8.

Arivoli S, Samuel T (2011) Studies on the mosquitocidal activity of Murraya koenigii (L.) Spreng (Rutaceae) leaf extracts against Aedes aegypti, Anopheles stephensi and Culex quinquefasciatus (Diptera: Culicidae). Asian Journal of Experimental Biological Science 2: 721-730.

Armadhani (2014) Keefektifan Ekstrak Etanol Daun Petai Cina (Leucaenaglauca, Benth) sebagai Larvasida Alamiterhadap Kematian Larva Nyamuk Ae. aegypti Instar III. NaskahPublikasi. Semarang: Universitas Negeri Semarang.

Aziz SSSA, Sukari MA, Kitajima M, Aimi N, Ahpandi NJ (2010) Coumarins from Murraya paniculata (Rutaceae). Malaysian Journal of Analytical Sciences 14: 1-5.

Bagavan A, Rahuman AA, Kamaraj C, Geetha K (2008) Larvicidal activity of saponins from Achyranthes aspera against Aedes aegypti and Culex quinquefasciatus (Diptera: Culicidae). Parasitology Research 103: 223-229.

Bilal H, Akram W, Ali-Hassan S (2012) Larvicidal activity of Citrus limonoids against Aedes albopictus larvae. Journal of Arthropod-Borne Diseases 6: 104-111.

Boham A Kocipai AC (1974) Flavonoids and condensed tannins from leaves of Hawaiia vaccinum vaticulatum and $V$. calyscinium. Pacific Science 48: 458-463.

Borah R, Kalita MC, Kar A, Talukdar AK (2010) Medicinal plants and their applications. African Journal of Biotechnology 9: 25-27.

Boudko DY, Moroz LL, Harvey WR, Linser PJ (2011) Alkalinization by chloride bicarbonate pathway in larval mosquito midgut. Proceedings of the National Academy of Sciences of the United States of America 26: 15355-15359.

Bradford MM (1976) A rapid and sensitive method for the quantitation of microgram quantities of protein utilizing the principle of protein-dye binding. Analytical Biochemistry 72: 248-254.

Cardoso-Lopes EM, Maier JA, Da Silva MR, Regasini LO, Simote SY, Lopes NP, Pirani JR, Bolzni VS, Young MCM (2010) Alkaloids from stems of Esenbeckia leiocarpa Engl. (Rutaceae) as potential treatment for Alzheimer disease. Molecules 15: 9205-9213.

Chapagain B, Saharan V, Wiesman Z (2008) Larvicidal activity of saponins from Balanites aegyptiaca callus against Aedes aegypti mosquito. Bioresource Technology 99: 1165-1168.

Damerval C, De Vienne C, Zivy M, Thiellement H (1986) The technical improvements in two-dimensional electrophoresis increase the level of genetic variation detected in wheat seedling proteins. Electrophoresis 7: 52-54.

Das NG, Goswami D, Rabha B (2007) Preliminary evaluation of mosquito larvicidal efficacy of plant extracts. Journal of Vector Borne Disease 44: 145-148.

de Souza Wuillda ACJ, Martins RCC, Costa FN (2019) Larvicidal activity of secondary plant metabolites in Aedes aegypti control: An overview of the previous 6 years. Natural Product Communications 1: 1-11.

El-Akhal F, Lalamia AEO, Guemmouh R (2015) Larvicidal activity of essential oils of Citrus sinensis and Citrus aurantium (Rutaceae) cultivated in Morocco against the malaria vector Anopheles labranchiae (Diptera: Culicidae). Asian Pacific Journal of Tropical Disease 5: 458-462.

Elimam AM, Elmalik KH, Ali FS (2009) Efficacy of leaves extract of Calotropis procera Ait. (Asclepiadaceae) in controlling Anopheles arabiensis and Culex quinquefasciatus mosquitoes. Saudi Journal of Biological Sciences 16: 95-100.

Ezeonu FC, Chidume GI, Udedi SC (2001) Insecticidal properties of volatile extracts of orange peels. Bioresource Technology 76: 273-274.

Farooq U, Waseem B, Muzaffar R, Tripathi J, Tharani M, Sharma MA (2014) Comparative study of phytochemical investigation of Xanthium strumarium medicinal plant. International Journal of Research in Pharmacy and Chemistry 4: 96-100.

Galvão JG, Silva VF, Ferreira SG, França FRM, Santos DA, Freitas LS, Alves PB, Araújo AAS, Cavalcanti SCH, Nunes RS (2015) Cyclodextrin inclusion complexes containing Citrus sinensis (L.) Osbeck essential oil: An alternative to control Aedes aegypti larvae. Thermochimica Acta 608: 14-19.

Garcez WS, Garcez FR, Silva L, Sarmento UC (2013) Substâncias de origem vegetal com atividadelarvicida contra Aedes aegypti. Revista Virtual de Química 5: 363-393. 
George UI (2019) Environmental control of malaria: Can Citrus sinensis peel be a potent larvicide for household vector control? GSC Biological and Pharmaceutical Sciences 09(03): 085-090.

Ghosh A, Chowdhury N, Chandra G (2012) Plant extracts as potential mosquito larvicides. Indian Journal of Medical Research 135(5): 581-598.

Harborne JB (1998) Phytochemical methods, a guide to modern techniques of plant analysis, $3^{\text {rd }}$ Edition. Chapman and Hill Ltd., London, 279.

Hemingway J, Beaty BJ, Rowland M, Scott TW, Sharp BL (2006) The innovative vector control consortium: Improved control of mosquito-borne diseases. Trends in Parasitology 22: 308-312.

Hostettmann K, Marston A (1995) Saponins (Chemistry and Pharmacology of Natural Products). University Press, Cambridge, 132.

Huang HT, Lin CC, Kuo TC, Chen SJ, Huang RN (2019) Phytochemical composition and larvicidal activity of essential oils from herbal plants. Planta 250: 59-68.

Ileke KD, Ogungbite OC (2015) Alstonia boonei De Wild oil extract in the management of mosquito (Anopheles gambiae), a vector of malaria disease. Journal of Coastal Life Medicine 3: 557-563.

Isman MB (1997) Neem and other botanical insecticides: Barriers to commercialization. Phytoparasitica 25: 339-344.

Ito C (2000) Studies on medicinal resources of rutaceous plants and development to pharmaceutical chemistry. Natural Medicine 54: 117-122.

Kaushik S, Sharma NR, Thomas TG, Sharma AK, Bansal A (2019) Indigenous plants and their larvicidal potential against Indian mosquito vectors: A review. Journal of Communicable Diseases 51: $59-72$

Kumar S, Ray A, Kaur J, Samal R, Wahab N, Warikoo R (2012) Efficacy of the ethanolic leaf extracts of citrus plant, Citrus sinensis as larvicidal and irritant agent against dengue vector Aedes aegypti L. Asian Pacific Journal of Tropical Biomedicine 3: 152-155.

Laemmli UK (1970) Cleavage of structural proteins during the assembly of the head of bacteriophage T4. Nature 227: 680-685.

Lee KP, Simpson SJ, Wilson K (2008) Dietary protein-quality influences melanization and immune function in an insect. Functional Ecology 22: 1052-1061.

Lowry OH, Rosebrough NJ, Farr AL, Randall RJ (1951) Protein measurement with the Folin phenol reagent. Journal of Biological Chemistry 193: 265-275.
Mandal S, Nayak A, Kar M, Banerjee SK, Das A, Upadhyay SN, Singh RK, Banerji A, Banerji J (2010) Antidiarrhoeal activity of carbazole alkaloids from Murraya koenigii Spreng (Rutaceae) seeds. Fitoterapia 81: 72-74.

Mann RS, Kaufman PE (2012) Natural product pesticides: their development, delivery and use against insect vectors. MiniReviews in Organic Chemistry 9: 185-202.

Mansour SA, Messeha SS, Mohamed SM (1998) Botanical biocides: Mosquitocidal activity of certain Nigella sativa constituents. Journal of Union Arab Biology 10: 45-63.

Marin G, Arivoli S, Samuel T (2020) Synergistic larvicidal action of Citrus limon (L.) Osbeck (Rutaceae) and Bacillus thuringiensis Berliner 1915 (Bacillaceae) against the dengue vector Aedes aegypti Linnaeus 1762 (Diptera: Culicidae). GSC Biological and Pharmaceutical Sciences 10: 25-33

Murugan K, Kumar PM, Kovendan K, Amerasan D, Subrmaniam J, Hwang JS (2012) Larvicidal, pupicidal, repellent and adulticidal activity of Citrus sinensis orange peel extract against Anopheles stephensi, Aedes aegypti and Culex quinquefasciatus (Diptera: Culicidae). Parasitology Research 111: 1757-1769.

Musau JK, Mbaria JM, Nguta JM, Mathiu M, Kiama SG (2016) Phytochemical composition and larvicidal properties of plants used for mosquito control in Kwale County, Kenya. International Journal of Mosquito Research 3: 12-17.

Nathan SS (2020) A review of resistance mechanisms of synthetic insecticides and botanicals, phytochemicals, and essential oils as alternative larvicidal agents against mosquitoes. Frontiers in Physiology 10: 1591.

Obadoni BO Ochuko PO (2001) Studies and comparative efficacy of the crude extracts of some homostatic plants in Edo and Delta states of Nigeria. Global Journal of Pure and Applied Science 8b: 203-208.

Okwu DE, Okwu ME (2004) Phytochemicals and vitamins content of indigenous plant species of south eastern Nigeria. Journal of Sustainable Agriculture and Environment 6: 30-37.

Palanikumar M, Pravin Y, Navaneethan M, Mahendren S, Mohanraj RS, Dhanakkodi B (2017) Callistemon citrinus (Myrtaceae) methanolic leaf extract: a potent mosquitocidal agent for controlling dengue vector mosquito Aedes aegypti (Diptera: Culicidae). Journal of Entomology and Zoology Studies 5: 1051-1059.

Pathak M, Kumar R, Singh MK, Maurya O, Bharati KA (2018) A review on traditional larvicidal plants. Mintage Journal of Pharmaceutical \& Medical Sciences 7: 1-9 
Pitasawat B, Champakaew D, Choochote W, Jitpakdi A, Chaithong U, Kanjanapothi D, Rattanachanpichai E, Tippawangkosol P, Riyong D, Tuetun B, Chaiyasit D (2007) Aromatic plant-derived essential oil: an alternative larvicide for mosquito control. Fitoterapia 78: 205-210.

Pollio A, De Natale A, Appetiti E, Aliotta G, Touwaide A (2008) Continuity and change in the Mediterranean medical tradition: Ruta spp. (Rutaceae) in Hippocratic medicine and present practices. Journal of Ethnopharmacology 116: 469-482.

Rajkumar S, Jebanesan A (2008) Bioactivity of flavonoid compounds from Poncirus trifoliata L. (Family: Rutaceae) against the dengue vector, Aedes aegypti L. (Diptera: Culicidae). Parasitology Research 104: 19-25.

Rey D, Pautou MP, Meyran JC (1999) Histopathological effects of tannic acid on the midgut epithelium of some aquatic Diptera larvae. Journal of Invertebrate Pathology 73: 173-181.

Samuel T, Arivoli S, William J (2016) Phytonanopesticides for vector control: A review. Journal of Applied Zoological Researches 27: 1-11.

Samuel T, Kalarani A, Vinodha V, Arivoli S, Selvakumar S, Meeran M, Syedalifathima A (2019) Repellent property of plants against mosquitoes in field conditions by traditional method. International Journal of Zoology and Applied Biosciences 4: 258-263.

Samuel T, William SJ (2014) Potentiality of botanicals in sustainable control of mosquitoes (Diptera: Culicidae). In: Achieving Sustainable Development: Our Vision and Mission, Ed. William, SJ, Loyola College, Chennai, Tamil Nadu, India 204-227.

Sattar M, Iqbal MN, Ashraf A, Ali S, Shahzad MI, Alam S, Ali T, Sheikh R (2016) Larvicidal efficacy of Citrus sinensis extracts against Culex quinquefasciatus. PSM Microbiology 1: 56-61.

Scherer R, Wagner R, Meireles MAA, Godoy HT, Duarte MCT, Filho JT (2010) Biological activity and chemical composition of hydrodistilled and supercritical extracts of Xanthium strumarium L. leaves. Journal of Essential Oil Research 22: 424-429.

Senthilkumar A, Kannathasan K, Venkatesalu V (2008) Chemical constituents and larvicidal property of the essential oil of Blumea mollis (D. Don) Merr. against Culex quinquefasciatus. Parasitology Research 103: 959-962.

Senthilkumar N, Varma P, Gurusubramanian G (2009) Larvicidal and adulticidal activities of some medicinal plants against the malarial vector, Anopheles stephensi Liston. Parasitology Research 104: 237-244.

Severino VG, Cazal CM, Forim MR, da Silva MF, Rodrigues-Filho E, Fernandes JB, Vieira PC (2009) Isolation of secondary metabolites from
Hortia oreadica (Rutaceae) leaves through high-speed counter-current chromatography. Journal of Chromatography A 1216: 4275-4281.

Sharma P, Mohan L, Srivastava CN (2006) Phytoextract-induced developmental deformities in malaria vector. Bioresource Technology 97: 1599-1604.

Siddique S, Javed S, Nawaz S, Perveen Z, Khan RA, Khanum R, Shahzad K (2012) Volatile components and antimicrobial activity of Citrus sinensis var. mosammi leaves oil. Journal of Medicinal Plants Research 6: 2184-2187.

SPSS (2010) IBM SPSS Statistics for Windows, Version 22.0. Armonk, NY: IBM Corp.

Sukari MA, Noor HSM, Bakar NHA, Ee GCL, Ismail IS, Rahmani M, Abdul AB (2013) Larvicidal carbazole alkaloids from Murraya koenigii against dengue fever mosquito Aedes aegypti Linnaeus. Asian Journal of Chemistry 25: 7719-7721.

Van Burden TP, Robinson WC (1981) Formation of complexes between protein and tannin acid. Journal of Agricultural Food Chemistry 1: 77 .

Visveshwari M, Subbaiyan B, Thangapandian V (2017) Phytochemical analysis, antibacterial activity, FTIR and GCMS analysis of Ceropegia juncea Roxb. International Journal of Pharmacognosy and Phytochemical Research 9: 914-920.

Wansi JD, Wandji J, Meva'a ML, Waffo KAF, Ranjit R, Khan SN, Asma A, Iqbal CM, Lallemand MC, Tillequin F, Tanee FZ (2006) Alpha-glucosidase inhibitory and antioxidant acridone alkaloids from the stem bark of Oriciopsis glaberrima Engl. (Rutaceae). Chemical and Pharmaceutical Bulletin 54(3): 292-296.

Warikoo R, Ray A, Sandhu JK, Samal S, Wahab N, Kumar S (2012) Larvicidal and irritant activities of hexane leaf extracts of Citrus sinensis against dengue vector Aedes aegypti L. Asian Pacific Journal of Tropical Biomedicine 2: 152-155.

Warren M, McGeoch MA, Nicolson SW, Chown SL (2006) Body size patterns in Drosophila inhabiting a mesocosm: interactive effects of spatial variation in temperature and abundance. Oecologia 149: 245-255.

WHO (2005) Guidelines for laboratory and field testing of mosquito larvicides. WHO, Geneva, WHO/CDS/WHOPES/GCDPP/13.

WHO (2014) A global brief on vector-borne diseases. WHO/DCO/WHD/2014.1

Zoubiri S, Baaliouamer A (2014) Potentiality of plants as source of insecticide principles. Journal of Saudi Chemical Society 18: 925-938. 